\title{
Map of Archaeological Sites Tracts Adzhiel in the Eastern Crimea, According to Different Sources
}

\author{
Viktor Gennadievich Zubarev ${ }^{1} \&$ Sergey L'vovich Smekalov ${ }^{1}$ \\ ${ }^{1}$ Tula State Lev Tolstoy Pedagogical University, Russia \\ Correspondence: Sergey L'vovich Smekalov, Tula State Lev Tolstoy Pedagogical University, Tula 300026, \\ Russia.E-mail: mtrushin@mail.ru
}

Received: October 25, 2014

Accepted: November 6, $2014 \quad$ Online Published: January 11, 2015

doi:10.5539/mas.v9n3p184

URL: http://dx.doi.org/10.5539/mas.v9n3p184

\begin{abstract}
Publication devoted to the study, by means of geo-information system, of one of the districts of the Kerch Peninsula - Tracts Adzhiel - the territory adjacent to the gully Adzhiel and her sleeves. The important ways of migration of the Scythians and other peoples from Europe to Asia, probably, passed there in ancient times. And also there are located one of the largest on the peninsula ancient fortified settlement "Belinskoye", as well as many other monuments. The study of the territory was carried out on the squares of the graticule military topographic maps of the General Headquarters of the Soviet Union a scale of 1: 100,000. As the information sources, were used old topographic maps Russia of the end XIX century, scale 1: 42,000 (the so-called "verstovka" - 1 "versta" - 1066,8 m in one inch), maps of the General Headquarters of the Soviet Union, scale 1: 25,000 , aerial photographs of the 70-es of XX century, space images of Google Earth, the data presented in scientific publications and reports. The results lead to the conclusion that on the survey area in the XIX century there were at least 150 barrows of which are currently on satellite images clearly visible only 22 and at least 12 other types of archaeological sites - settlements, ground necropols, fortifications, most of which were not previously the subject to archaeological excavations. The detailed study of these objects is planned already on the ground in the course of future work.
\end{abstract}

Keywords: Crimea, Kerch Peninsula, tract Adzhiel, Bosporan Kingdom, Belinskoye settlement, archeology, antiquity, geographical information systems, old maps, space imagery, aerial photography

\section{Introduction}

Generalization and systematization of knowledge about the cultural and historical monuments is a problem that is acute in any civilized country. The relevance of such work in the Crimea is due to the fact that here there will be in the coming years run an extremely large amount of work associated with its revival as a large resort and tourist area and an important agricultural region. In the Crimea placed thousands of archaeological sites of different periods and of different types. Creation of the archaeological map, reflecting the current level of available information about these objects, is necessary for historical and archaeological researches, for the development of cultural tourism, solving the problems related to the economic use of the areas, where there are archaeological sites.

This problem is not new to the Russian and Ukrainian archeology. Dozens of expeditions from Ukraine, Russia, Poland, Germany and other countries carry archaeological research in the Crimea. However, the work of archaeologists is associated in most cases with the study of individual monuments, and there are not so many researches dedicated to the study of the area. Until recently, there were no printed books, containing a detailed list of known archaeological sites of the Eastern Crimea, except the monograph of I.T. Kruglikova (Kruglikova, 1975). After the publication of this work has been almost 40 years. Over these years have been discovered and studied many new objects, but the compilation of data about these objects for the whole territory of the Eastern Crimea was not issued. However, for the chora of the ancient city of Nymphaeum, located near the southern edge of the modern city of Kerch, chora of Feodosia, for the part of the Azov sea coast of the Kerch Peninsula, composed of highly detailed descriptions, and, in some cases, archaeological maps of individual areas (Sholl and Zin'ko, 1999; Zin'ko, 2003; Gavrilov, 2004; Maslennikov, 2008). In 2005, the Institute of Archaeology of the Russian Academy of Sciences have been published diaries of V.V. Veselov (Veselov, 2005) - researcher, who long time (1949-1964) engaged in a systematic archaeological survey of the territory of the Eastern Crimea. In 
these diaries provides information about 704 archaeological sites located in the Kerch Peninsula. However, due to the fact that in the years when VV Veselov made his investigations, accurate maps were secret, he could give only a rough description of the position of objects, so that in fact, many of them should be now open again. The very important information about archaeological objects, especially, about the barrows, is also represented on the old maps of the late XIX century, in the first place on the map scale 1: 42000 (Map, 1890). A comparison of the available results of archaeological research, information that can be obtained from old and modern maps, aerial and space images, using geographic information technologies, allows us to construct the preliminary archaeological maps for subsequent work in the field to identify the objects, which are present in reality. As the study area is selected the tract Adzhiel (Note 1). The tract is one of the districts of the Eastern Crimea, which played an important role in ancient times. The gully Adzhiel going in the direction northwest-southeast. It is difficult for crossing, separates off a significant part of the Kerch Peninsula, and is one of the natural protective boundaries of the Eastern Crimea. The forces of garrisons of fortified settlements stationed here and, in the first place, the garrison of the large ancient settlement "Belinskoye" (Zubarev, 2004; Atlas, 2000) probably had controlled the most walkable places where in ancient times were, obviously, the shortest paths of migration from the mainland through the Crimea to Taman. Thus, this area is likely, had played a strategic role in the defense system of the Bosporan kingdom, and the very settlement "Belinskoye" was, perhaps, a local political center.

\section{Method}

Methodology for conducting a full archaeological survey of the area is very detail presented in the published in 1939 book of A.A. Mansurov "Method of archaeological map" (Mansurov, 1939). There were summarized and detail set out the basic principles of the archaeological description of region and methods of the field work. In fact, they are used with more or less modifications by archaeologists all over the former Soviet Union. The most important in recent years become possible to fix the exact coordinates of detected objects by GPS and the ability to pre-study the areas with the help of large-scale satellite images. However, one from the main approaches in the work of AA Mansurov - survey of the territory not in accordance with the administrative, natural or historical boundaries, but in accordance with the nomenclature of topographic maps, for subsequent cross-linking with the adjacent areas, has not found its embodiment in the works in Russia and Ukraine, known to the authors. Similar approaches, as to the principles of construction of archaeological maps, so as in the practical organization of work on the ground is used, taking into account the changes in the technical capabilities are used by archaeologists from other countries too (Spier, 1970; Nevada, 2012; Risbøl et al., 2003). It should also be noted that in the preparation of an archaeological map, the selection of areas where there are no archaeological sites, are not less important, than the designation of the monuments themselves. Unfortunately, in most cases it is not reflected in the publications and in the archaeological reports. In the most cases there are not listed the tracks of reconnaissance routes, the contours of the surveyed areas, where monuments were found, not specified the density of survey routes.

In accordance with the above, the studying of the tracts Adzhiel was conducted on the squares of the graticule on sheets of topographic maps with a scale of 1: 100,000. These cards are now the most large-scale maps, available in the public domain. Each square has a size of $2 \times 2 \mathrm{~km}$, which allows you to display the corresponding region on a single sheet in $\mathrm{A} 4$, on the scale of 1: 10,000 (100 $\mathrm{m}$ in one centimeter). This is enough to highlight the individual characters of objects, spaced at a distance of more than $10 \mathrm{~m}$, and allows, in most cases, clearly the identification of objects on the ground. The numbering of the squares was conducted in accordance with the coordinates of the southwest corner of the square, marked on topographic maps of the General Headquarters of the USSR (the Gauss-Kruger coordinate system for the Krasovskii ellipsoid - Pulkovo 1942).

Analysis was performed for squares $(28-32) 70$; $(26,28)(72-74)$ of topographic map L-37-85 scale 1:100000, which include the tract Adzhiel and some surrounding areas (Figure 1). For analysis was prepared the geographic information system, which includes the following main layers: the maps of scale 1: 126000 1862-1876 (Map, 1862); the map of scale 1: 42,000, the late XIX century; maps of the General Headquarters of the USSR, scale 1: 25,000 50-s XX century and the scale of 1: 100,000 80-s XX century; layer of aerial photographs 70-s. XX century; layer of modern space imagery Google Earth; layer of known archaeological monuments, which coordinates are in the database, created by the authors (Smekalov, 2010). Description of monuments in the database was conducted in accordance with international standards for the description of archaeological sites (Standard, 1998). 


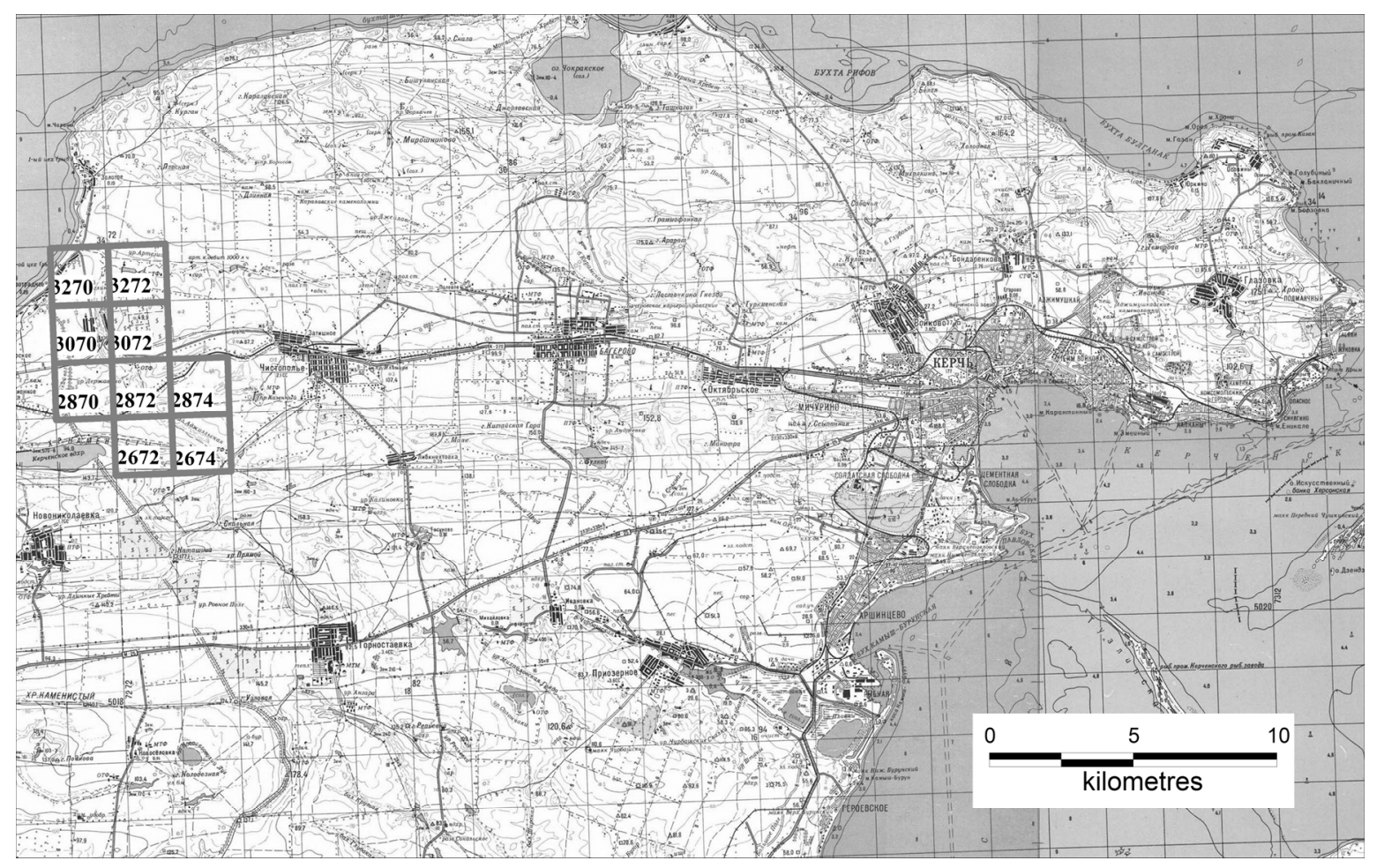

Figure 1. Location of the study area on the map of the Kerch Peninsula

\section{Results}

\subsection{Square 3270}

In the eastern part of the square (Figure 2) is the village Novootradnoe. Previously, in the XIX century there was located here a small hamlet Adzhibay (10 yards) and a mosque. Along the eastern boundary of the square the gully Adzhiel passes, connecting to the gully Artesian in the northeast corner of the square, which go further along the northern boundary of the square, and empties into the sea. The central and southern parts of the square are occupied by agricultural fields. From the known objects in the northern part of the square situated the ancient settlement of Novo-Otradnoe I, which existed from the II BC to the beginning of the IV AD. Settlement has \# 185 in (Kruglikova, 1975). Excavations of the settlement carried out in 50-70-s last century by I.T. Kruglikova and other researchers (Kruglikova, 1975, 1998). According to I.T. Kruglikova, it was a fortified farmstead, area of 0,044 hectares. Inside the defensive wall, which was the outer wall of the farmstead, were the premises and patios. Apparently, the boundaries of the farmstead had not been changed from II BC. when the first outside walls of the farmstead, square in the plan were built. Restructing concerned only the interior layout. Life of the farmstead ends in IV AD, perhaps as a result of the attack of the Huns. Settlement is clearly visible on space images. To the north-east from the village Novootradnoe the settlement of the Roman period is located, indicated in the B.B. Veselov diary under \# 521 (Veselov, 2005). Although the description of the location is similar to the location of the settlement of Novo-Otradnoe I, but V.V. Veselov indicates that discovered it in 1962, but excavations of Novo Otrddnoe I, were launched in 1953. Thus, where the monument, which marked Veselov is not known. Veselov did not lead any characteristics of the detected structures. Time of the settlement probably carried out by the found fragments of pottery. 


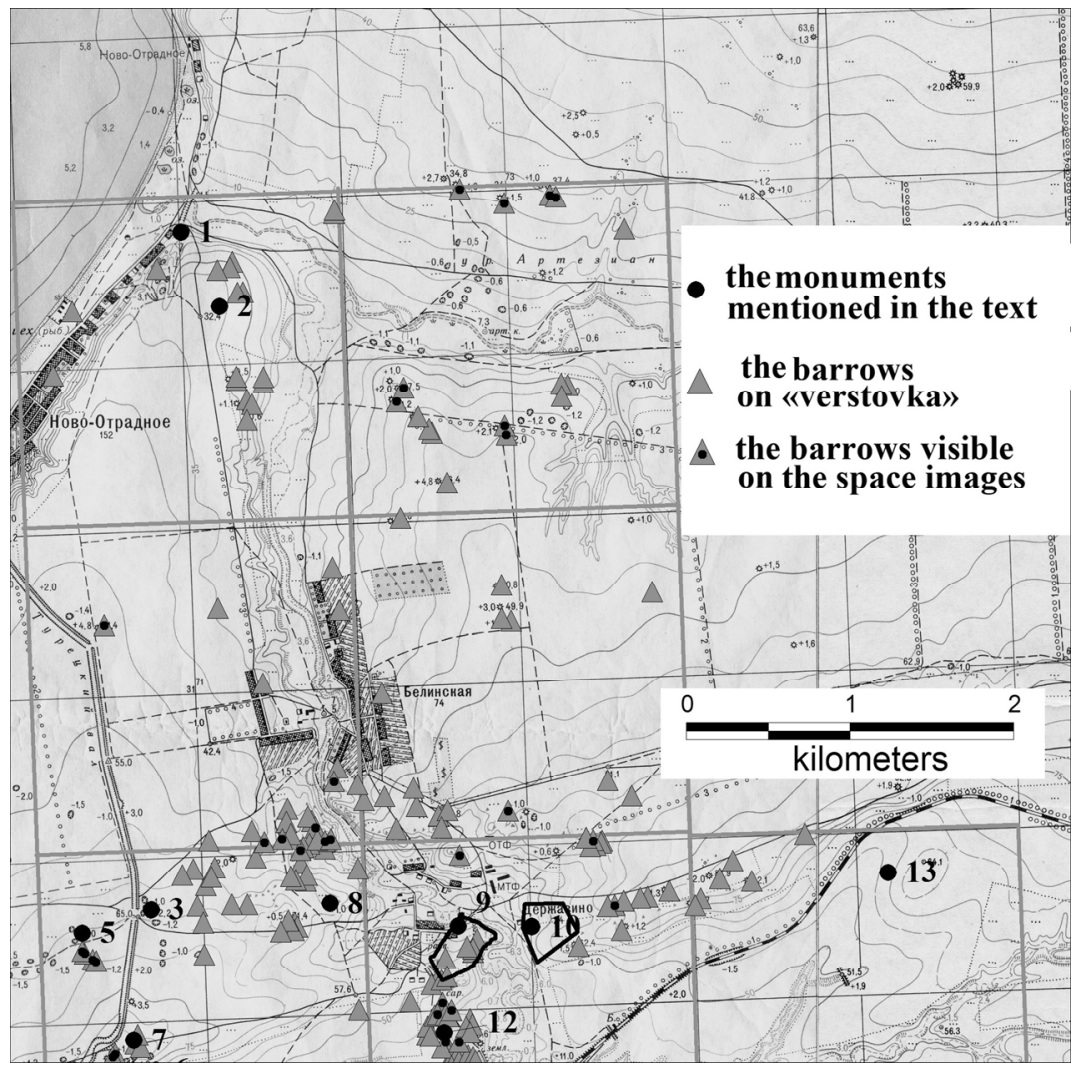

Figure 2. Archaeological sites in squares 3270, 3272, 3070, 3072

Also on the maps of XIX and 50-es of XX centuries in this square indicated 16 barrows. It seems that now these barrows are completely destroyed, as no embankments, or even specific circles, remaining at plowing, on space and aerial photographs, is not visible. Although, of course, the points at which previously placed the barrows should be carefully investigated. On the basis of space images is difficult definitely assumed that there still any ancient man-made structures, however, but during the walking survey, it is necessary to focus on the north-eastern part of the square, which is not affected by plowing and construction.

\subsection{Square 3272}

The central part of the square (Figure 2) takes a pond, the gully Artesian mainstream and adjoined ravines in the eastern part of the square. Near the pond, which appeared probably in the second half of the XX century, on the XIX century maps designated Ilyin's farmhouse and garden. The rest of the territory is occupied currently fields. On "verstovka" and the map scale 1: 25,000 within a square indicated 18 mounds. 9 of them are probably quite well preserved and clearly visible on space and aerial photographs, the traces of the others do not show up. There are no any more possible archaeological objects in the square.

\subsection{Square 3070}

In the western part of the square (Figure 2) is situated Uzunlar rampart - the grandest monuments of field fortifications in the Crimean peninsula. The study of this monument are dedicated the dozens of works, excavations were conducted repeatedly on some of its parts. Present state of knowledge of the object and the story of the researches presented in detail in the work (Maslennikov, 2003). In the north-western corner of the square, about 150 meters from the ramparts, there is a large barrow. Perhaps it is referring to his A.A. Maslennikov (Maslennikov, 2003), mentioning about plundered burial with a stone box. The central part of the eastern half of the square is occupied by the modern village Belinskoe. In the area of modern buildings and the surrounding gardens, on "verstovka" denote 4 barrows, but they probably were completely destroyed not later than the first half of the XX, since on the maps of the second half of the XX century is not marked. In the south-eastern part of the square on the "verstovke" indicated about 20 mounds, but on the map scale 1: 25,000 in the same area shown outputs stony rocks. Signs of hills are visible on space images. Thus, to identify the nature of these objects necessary ground survey. 


\subsection{Square 3072}

The mid-western part of the square (Figure 2) takes a village Belinskoye, the rest of the western half of the square - mainly cultivated fields. The entire eastern half seems now uncultivated steppe. Characteristic traces of plowing are not visible here. In the northern half of the square on the maps of the XIX century and 50-es of XX century. designated several barrows, but, apparently, in the second half of XX century. they were destroyed, because they are not visible in the space images. In the southern part - the continuation of the chain of barrows, or the outputs of stones, as well as in the south-eastern part of the square 3070.

\subsection{Square 2870}

The square (Figure 3), is mainly occupied by fields, partly they are cultivated. In the south is a railroad. Through the eastern half of the square passes Uzunlar rampart. In the northern and eastern part of the "verstovka" XIX century indicated 16 barrows. In the northern part of the square on the rampart and near the rampart held in 2000-2002 archaeological excavations (Maslennikov, 2003). Were carried out excavations of the rampart, and a small hill east of the rampart, which was enough powerful detached building - tower, or even, perhaps, a small fort. It is possible that some of the hills near the rampart mounds in the reality conceal the defense constructions. In particular, probably the remains of a defensive tower hides mound on top of the mountain Kermenchik in the south-eastern part of the square. In addition, in the northwestern part of the square marked the earthen shafts \# 436 (Veselov, 2005), the time and purpose are not clear. These shafts are viewed on space images. To the east of the mountains Kermenchik, located settlement, presumably IV-III centuries BC, marked \# 433 (Veselov, 2005) and \# 180 (Kruglikova, 1975). Another settlement of the same time is located on the northeastern slope. By V.V. Veselov it noted under \# 432, but I.T. Kruglikova does not mention about it . Perhaps we are talking about different parts of the same settlement that \# 433. There were no excavations of this monument. Finally, it could be noted the barrow with a stone lining and a thief's pit on a hilltop "Uch Oba" in the north-east corner of the square. This barrow is marked on the map 1: 25,000 of the XX century, but on "verstovka" of XIX not stated separately, the whole hill is marked as barrow "Uch Oba".

\subsection{Square 2872}

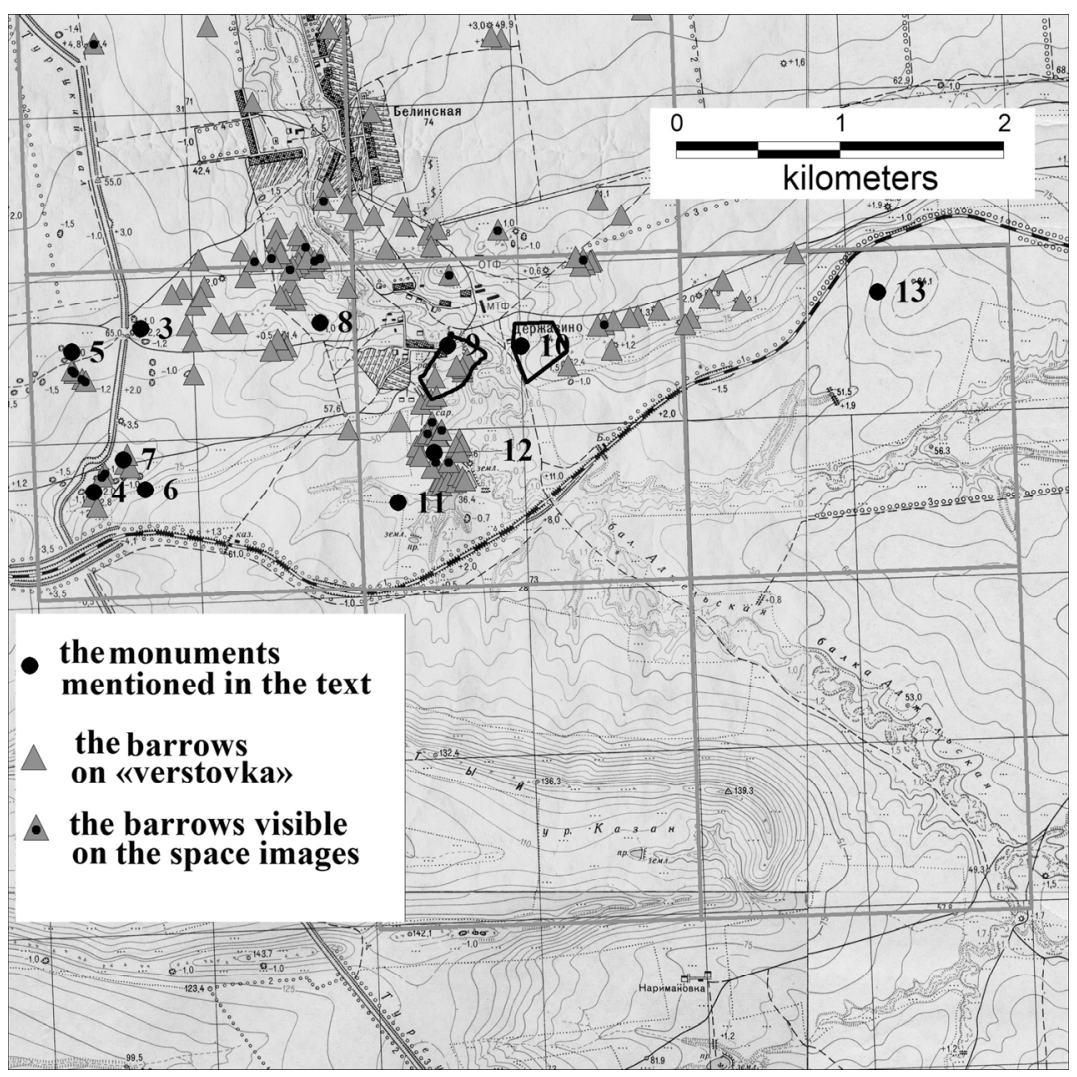

Figure 3. Archaeological sites in squares 2870, 2872, 2874, 2672, 2674 
On the diagonal of the square (Figure 3) from the north-west corner to the south-east, passes the gully Adzhiel.

The sleeves of the gully and flows into her gully Kudachi-Bathtan occupy almost the entire southern part of the square. The rest of the territory is occupied the fields, for the most part, with the exception of the northeast corner, uncultivated. Across the square from the south-west corner, to about the middle of the eastern boundary is the line of the railway. In the south-west corner of the square in the late XIX was the village Adzhiel with 28 yards and a mosque (after 1948 - Derzhavino). At the moment it is completely destroyed. In the center of the square, on the plateau, an area of more than 8 hectares of which the north and east bypasses the gully Adzheli, is the ancient settlement "Belinskoye." The name of the monument is associated with the nearest settlement Belinskoye village, located about a mile north-west of the ancient settlement. First mention of the settlement is found in the manuscript of chronicles guarding excavations of Kerch Historical-Archeological Museum, by S.S. Bessonova early 50-es XX century. At different times (70-80 XX century.) settlement was surveyed by I.T. Kruglikova, O.D. Chevelev, A.A. Maslennikov (Maslennikov, 1998; Maslennikov, Chevelev, 1981). In its place, presumably localized antique town Tafr mentioned in Claudius Ptolemy (III, 6, 5) (Nobbe, 1843). The monument is in the protection register under number 2990. Systematic excavations conducted since 1996 by an expedition of Tula State Pedagogical University (Zubarev, 2004). Monument dates from I-II - mid-V BC. Area of the town within the defensive wall of 8.2 hectares. This is one of the largest settlements of the ancient Eastern Crimea. To the east of the settlements on the opposite side of the gully is a necropolis with lots of stone vaults. Contoured area of the necropolis occupies 7.8 hectares, but recent studies have shown that, probably, it is continued in an easterly direction, where on "verstovka" denotes a chain of 5 barrows. Preliminary inspection of the area in 2013 showed that the numbers of barrows considerably more, and the earliest, probably belong to the Bronze Age. Based on the same map, the substantial accumulation of barrows located in the middle of the western half of the square. Barrows that are closest to the ancient settlement are likely to be the not burial structure, but the ash hills. Most of these mounds are not visible on the satellite and aerial images that speaks to their small size, or the destruction in the XX century. In the south-west quarter of the square, apparently, there are two more settlements Derzhavino II \# 434 (Veselov, 2005), \# 181 (Kruglikova, 1975) and Derzhavino III \# 435 (V Veselov, 2005) \# 182 (Kruglikova, 1975). The researchers attributed these settlements to I-III centuries BC. However, the exact location of these sites is not known. Researchers do not lead the characteristics of the detected structures. Dating probably carried out by the found fragments of pottery.

\subsection{Square 2874}

In the north-western corner of the square (Figure 3) passes continued barrows chain going from the necropolis of ancient settlement Belinskoye. On "verstovka" indicated 6 mounds but on space and aerial photographs they do not read. From the middle of the west side to the middle of the north the square is crossed by the railroad. The main part of the square takes the gully Kudachi-Batkaev. In the southeast corner of the square on the satellite images are visible the boundary of agricultural fields with traces of plowing. Somewhere in the north-eastern quadrant of the square, apparently located settlement IV-II centuries BC marked by V.V. Veselov under \# 561. The exact position of the object is not known.

\subsection{Square 2672}

Approximately through the middle of the square (Figure 3) in the direction of east-west the ridge "Kamenisty" passes, the maximum height is about $140 \mathrm{~m}$. Earth is probably not cultivated. The main part of the square is occupied by the slopes of the ridge. Through the north-east corner of the square passes the gully Adzhiel. Neither old nor modern maps in this square is not indicated the barrows, while in other areas of the peninsula, along the crests of ridges, barrows are often held chain. Perhaps this is due to the fact that in the next square to the east the ridge "Kamenisty" makes a loop and then the steppe overlaped by gully Adzhiel, making impossible the direct path to the east. Accordingly, through this area did not pass the communication path, and it is explain the absence of barrows. The other archaeological sites in this square are also not known.

\subsection{Square 2674}

In the south-west quarter of the square (Figure 3) the ridge "Kamenisty" makes a 180 degree turn. The remaining space of the square is almost entirely occupied the gully Adzhiel and its sleeves. Only in the north-east corner of the square in the satellite image can be noted cultivated fields. Barrows are not indicated within a given square on the maps. Also there is no information about the presence of any other archaeological objects from the available data in the literature.

Table 1 shows the location of known archaeological sites mentioned in the text by the squares of the next field survey. The numbering of the points corresponds to the numbers in Figures 2 and 3. 
Table 1. Coordinates of known archaeological sites (coordinates of the objects, the exact position of which is not known are shown in italics)

\begin{tabular}{|c|c|c|c|c|c|c|c|}
\hline $\begin{aligned} \text { \#п. } \\
\text { п. }\end{aligned}$ & $\begin{array}{r}\text { Number of } \\
\text { objects in the } \\
\text { data base }\end{array}$ & Titlee & $\begin{array}{r}\text { Number(Krug } \\
\text { likova,1975) }\end{array}$ & $\begin{array}{r}\text { Number(Vese } \\
\text { lov,2005) }\end{array}$ & Time & $\begin{array}{l}\text { Latitude,( } \\
\text { WGS-84) }\end{array}$ & $\begin{array}{r}\text { Longitude,г } \\
\text { рад.в.д. } \\
\text { (WGS-84) }\end{array}$ \\
\hline 1 & 163 & Novo-OtradnoeI & 185 & & IIc.BC.-IIIc.AD & 45,40122 & 36,07375 \\
\hline 2 & 4328 & V.V.Veselov\#521 & & 521 & Ic.BC.-Vc.AD & 45,39717 & 36,07678 \\
\hline 3 & 236 & Usunlarrampart.tower & & & & 45,36407 & 36,07144 \\
\hline 4 & 3443 & Usunlarrampart.tower & & & & 45,35512 & 36,0678 \\
\hline 5 & 4277 & V.V.Veselov\#436 & & 436 & & 45,3628 & 36,06608 \\
\hline 6 & 1318 & DerzhavinoI & 180 & 433 & IV-IIIcc.BC. & 45,35526 & 36,07181 \\
\hline 7 & 1319 & V.V.Veselov\#432 & & 432 & IV-IIIcc.BC. & 45,35691 & 36,07009 \\
\hline 8 & 2836 & BarrowUchOba & & & & 45,36441 & 36,08542 \\
\hline 9 & 75 & Belinskoyesettlement & 285 & & Ic.BC.-Vc.AD & 45,36317 & 36,0954 \\
\hline 10 & 1330 & Belinskoyenecropolis & & & & 45,36314 & 36,10114 \\
\hline 11 & 977 & DerzhavinooII & 181 & 434 & I-IIIIcc.AD & 45,35454 & 36,09153 \\
\hline 12 & 978 & DerzhavinooIII & 182 & 435 & 0 & 45,3573 & 36,09433 \\
\hline 13 & 4364 & V.V.Veselov\#561 & & 561 & IV-IIcc.BC. & 45,36613 & 36,12896 \\
\hline
\end{tabular}

\section{Discussion}

The preliminary study showed that in the area of gully Adzhiel in the XIX century on the ground there was not less than 150 barrows, of which at present most of the destroyed. However, the coordinates of these barrows can be determined according to the old maps, and these points on the ground require further study, and perhaps the excavation for the detection of residues of funerary structures located below the modern surface.

Of not less than 12 archaeological sites of other types only 5 were carried out archaeological excavations, and the 7-position is not accurately known, they require a "rediscovery" and research.

These results will be used for routing surveys on the ground with the GPS devices, in which will be loaded the prepared maps, satellite imagery and point location of known objects. Conducting these studies is planned in the coming years by the expedition of Tula State Lev Tolstoy Pedagogical University.

\section{Acknowledgments}

The study was conducted within the framework of of research project "Structural and spatial study of the monuments as a paradigm of the archaeological investigation of the history of a particular region (as example tracts "Adzhieli" and settlement "Belinskoye") at Tula State Lev Tolstoy Pedagogical University on the basis of the assignments \# 2014/389 to perform state works in the field of scientific activities of the base part of the state task the Ministry of Education and Science of the Russian Federation.

The authors express their gratitude to the staff of the Crimean branch of the Institute of Archaeology of the National Academy of Sciences of Ukraine, S. B. Lantsov, V.P. Vlasov and M.S. Shaptsevu for assistance in collecting the maps and information about the investigated archaeological sites.

\section{References}

Atlas. (2000). Barrington Atlas of the Greek and Roman World. In Richard J. A. Talbert (Ed.), Princeton University Press, 2000.

Gavrilov, A. V. (2004). District of ancient Theodosia. Simferopol: ABC.

Kruglikova, I. T. (1975). Agriculture Bosporus. Moscow.

Kruglikova, I. T. (1998). Settlement near the village of Novo-Otradnoe. (\# 1). Antiquities of the Bosporus. Moscow.

Mansurov, A. A. (1939). Method of archaeological map. Moscow. Commissariat of the RSFSR.

Map. (1890). Maps Tauride province. Scale 1: 42000. - Petrograd: Military Topographical Department, 1917-1920 (reprint).

Map. (1862). Military Topographic Map Tauride province 1862-1876. Scale 1: 126000. M.: Cartographic Section of the Army Corps of surveyors, 1920 (reprint). 
Maslennikov, A. A. (1998). Hellenic Choir at the edge Oecumene. Moscow.

Maslennikov, A. A. (2003). Ancient earthworks border fortifications of the Eastern Crimea. Moscow.

Maslennikov, A. A., \& Chevelev, O. D. (1981). New monuments of ancient times on the northern coast of the Kerch Peninsula. (\# 168, pp. 77-85). Brief reports of the Institute of Archaeology. Moskva.Nauka.

Maslennikov, A. A. (2008) Classical Antiquities Of The Crimean Azov Sea Coast: A. A. Anthropology \& Archeology of Eurasia, 47(1), 36-56.

Nevada. (2012). Guidelines and standards for archaeological inventory. Bureau of Land Management, Nevada.

Nobbe, C. F. A. (1843). Claudii Ptolemaei Geographia. (3 vols). Leipzig: Carolus Tauchnitus.

Risbøl, O, Risan, T, Bjørnstad, R., Fretheim, S., Håkon, B., \& Rygh, E. (2003). Kultuminner og kuiltumiljø $i$ Gråfjell Regionfelt Østlandet, Amot kommune i Uedmark. Arkeologiske registreringen 2002, faze 4., NUKU 125, NINA-NIKU, 2002, Oslo.

Sholl, T., \& Zin, k. V. (1999). Archaeological Map of Nymphaion, (Crimea). Warsaw: Institute of Arhaeology and Ethnology Polish Academy of Sciences.

Smekalov, S. L. (2010). Archaeological Map of the Crimea. Retrieved from: http://www.archmap.ru

Spier, R. F. G. (1970). Surveying and Mapping: A Manual of Simplified Techniques. Holt, Rinehart and Winston, New York.

Standard. (1998). Core Data Standard for Archaeological Sites and Monuments. Documenting the Cultural Heritage. Editors Robin Thornes John Bold. The J. Paul Getty Trust.

Veselov, V. V. (2005). A summary statement of the results of archeological explorations on the Kerch and Taman peninsulas in the 1949-1964 period. Antiquities of the Bosporus. Suppl. II. Moscow.

Zin, K. V. N. (2003). Choir of the Bosporus city Nymphaeum. Bosporus study. Simferopol, Kerch - V. IV

Zubarev, V. G. (2004). The ancient settlement near the village Belinskoye (Crimea). Bulletin of the Tula State Pedagogical University. L.N. Tolstoy. Humanities. Tula. \# 1.

\section{Note}

Note 1. On the modern and old maps are used different names for the area. In the literature often uses the word "Adzhiel". The settlement, which is associated with the name of the gully is designated as "Adzhiel" on "verstovka" and as "Derzhavino" on the map scale 1: 25,000, renamed in 1948 (Veselov, 2005). On the map scale 1: 100000 - part of the tract "Adzhiel" is designated as "the tract Derzhavino", the gully itself is called "Adzhielskaya ". One can also note the different spelling for the other names, "Novo-Otradnoe" in I.T. Kruglikova (Kruglikova, 1975) and "Novootradnoe" on the map scale 1: 100,000, and other maps. With that connected the differences in the text of this work.

\section{Copyrights}

Copyright for this article is retained by the author(s), with first publication rights granted to the journal.

This is an open-access article distributed under the terms and conditions of the Creative Commons Attribution license (http://creativecommons.org/licenses/by/3.0/). 